\title{
Antioxidant activity and free radicals of roasted herbal materials
}

\author{
ELŻBIETA WOJTOWICZ ${ }^{1 *}$, ALDONA KRUPSKA², RENATA ZAWIRSKA-WOJTASIAK ${ }^{3}$
}

\author{
Starołęcka 40 \\ 61-361 Poznań, Poland \\ ${ }^{2}$ Institute of Molecular Physics \\ Polish Academy of Sciences \\ Smoluchowskiego 17 \\ 60-179 Poznań, Poland \\ ${ }^{3}$ Faculty of Food Science and Nutrition \\ Poznań University of Life Sciences \\ Wojska Polskiego 28 \\ 60-637 Poznań, Poland
}

${ }^{1}$ Department of Food Concentrates and Starch Products

Prof. Wacław Dąbrowski Institute of Agricultural and Food Biotechnology

*corresponding author: phone +48 618731 989, e-mail: ewojt@man.poznan.pl

\section{Summary}

Introduction: Novel raw materials are being constantly searched for chicory coffee, which thanks to their specific composition can influence human health, thus promoting properties and of course the attractive aroma. Prior to their addition herbs - sea buckthorn (Hippophaë rhamnoides L.), rowanberry (Sorbus aucuparia L.), lovage roots (Levisticum officinale Koch) and dandelion (Taraxacum officinale coll.) - are roasted, which may change their antioxidant properties and generate free radicals with pro-oxidative properties.

Objective: The characteristic of antioxidant activity of roasted herbal raw materials (sea buckthorn fruits, rowanberry, lovage roots and dandelion roots) for the production of chicory coffee and to determine the level of free radicals formed under the influence of roasting.

Methods: Total phenolic contents were determined before and after the roasting process using the FolinCiocalteu phenol reagent and antioxidant activity by ABTS and DPPH assays. Free radicals were examined using electron paramagnetic resonance (EPR) spectroscopy.

Results: The roasted materials were good sources of bioactive compounds, estimated at the total phenolic levels from 23.9 to $38.8 \mathrm{mg}$ GAE/g. The highest antioxidant activity by ABTS and DPPH at 109.6 and $71.0 \mathrm{mg} \mathrm{Tx} / \mathrm{g}$ was determined in roasted sea buckthorn. Free radicals were present in both the raw and 
roasted herbal materials. Roasted materials were characterised by markedly higher free radical concentrations when compared with the corresponding samples. The lowest free radical concentrations were recorded for roasted sea buckthorn fruits $\left(0.031 \times 10^{15} \mathrm{spin} / \mathrm{g}\right)$.

Conclusion: Despite a high content of compounds with potent antioxidant activity, free radicals were present in novel roasted herbal materials. The formation of both antioxidant molecules and free radicals during the roasting process demonstrates that the two processes were not inversely related.

Key words: herbs, sea buckthorn fruits, rowanberry, lovage roots, dandelion roots, roasting process, antioxidant activity, free radicals

\section{INTRODUCTION}

Chicory coffee is a beverage known for centuries and at present it is classified to the group of products associated with a healthy lifestyle. It is an excellent alternative for individuals who enjoy the taste and aroma of coffee, but may not consume caffeine for health reasons. The aromatic value of chicory coffee is provided first of all by the production process, while the selection of raw materials is also important. Traditional raw materials include roasted chicory and cereal grains. Novel attractive raw materials are constantly being searched, which - thanks to their unique composition - would enhance the aroma of chicory coffee [1] or even make it resemble that of coffee beans [2]. Herbal raw materials (sea buckthorn fruits, rowanberry, lovage roots, dandelion roots) have been selected as components of chicory coffee due to their bioactive components exhibiting antioxidant properties [3-6]. However, before addition to chicory coffee these raw materials are subjected to the roasting process, which, similarly as in the case of coffee, on the one hand may cause changes in natural antioxidants (polyphenols and vitamins), while on the other hand they may generate free radicals with prooxidative properties $[7,8]$. Despite the high content of compounds with potent antioxidant activity, studies indicating that free radicals are present in coffee (roasted coffee beans, ground and instant coffee, and prepared beverage) were performed. In a study conducted by Goodman and Yeretzian $[7,8]$, free radical concentrations increased during roasting process.

Free radicals are atoms (or atom groups) with one or more unpaired electrons on the last electron shell. Their unique characteristics includes huge reactivity and the destructive effect on cell membrane structures. Free radicals are powerful oxidants. They oxidise compounds with phenolic, thiol and methionyl groups, resulting in damage to amino acids, proteins, hormones and enzymes, and they react with lipids of biological membranes. They are mutagenic and carcinogenic. Free radicals are analysed using electron paramagnetic resonance (EPR), a method exhibiting high specificity towards these molecules. It was shown that an excessive accumulation of free radicals in the organism as a result of disturbed redox potential equilibrium causes oxidative stress, responsible for the development of numerous diseases, including atherosclerosis, cancer, diabetes and Parkinson's disease, as well as aging [9-11].

Protection may be provided by substances capable of scavenging free radicals. In the organism, enzymatic and non-enzymatic systems comprises a group of endogenous antioxidants. The most important enzymatic antioxidants are superoxide dismutase, catalase and glutathione reductase. Non-enzymatic antioxidants are glutathione, uric acid as well as proteins: albumins, transferrin and melanins. Humans have no control over the level of endogenous antioxidants, thus we need to increase the amount of exogenous antioxidants supplied to the organism, e.g. ascorbic acid, $\alpha$-tocopherol, vitamin A, $\beta$-carotene and polyphenols both by increasing the share of vegetables and fruits in the diet and using herbs [12]. A number of studies deal with the antioxidant activity of herbs, medicinal plants and spices [13].

The aim of this study was to characterise the antioxidant activity of roasted herbal raw materials (sea buckthorn fruits, rowanberry, lovage roots and dandelion roots) for the production of chicory coffee by estimated antioxidant activity by ABTS, free radical scavengers of DPPH, total phenolic content and to determine the level of free radicals formed under the influence of roasting.

\section{MATERIAL AND METHODS}

\section{Standards and reagents}

Standards and reagents were as follows: 1,1-diphenyl-2-picrylhydrazyl radical (DPPH), 2,2-azino-bis 
(3-ethylbenzothiazoline-6-sulphonic acid (ABTS), 6-hydroxy-2,5,7,8-tetramethylchroman-2-carboxylic acid (Trolox), gallic acid, Folin-Ciocalteu reagent, sodium carbonate, potassium per sulphate, ethanol, methanol, acetone, formic acid and were obtained from Sigma-Aldrich (St. Louis, MO, USA).

\section{Materials}

Novel raw materials, i.e. sea buckthorn (Hippophaë rhamnoides L.), rowanberry (Sorbus aucuparia L.), lovage roots (Levisticum officinale Koch) and dandelion (Taraxacum officinale coll.) were purchased from Kawon-Hurt Company, Gostyń, Poland (commercial producer of herbal material). All novel raw materials were roasted. Samples before and after roasting were ground using a W Z1 laboratory mill (Sadkiewicz - Instruments, Bydgoszcz, Poland).

\section{Roasting treatment}

All novel raw materials were roasted in a BRZ 2 sample roaster battery (PROBAT, Emmerich am Rhein, Germany). Samples (100 g) were roasted in various conditions: $-160^{\circ} \mathrm{C}, 18 \mathrm{~min}$ for lovage and dandelion roots and $160^{\circ} \mathrm{C}, 8 \mathrm{~min}$ for other raw materials - to obtain dark roasts.

\section{Sample preparation}

The ground herbs $(0.5 \mathrm{~g})$ were extracted with $10 \mathrm{ml}$ of mixture water:acetone $(3: 7, v: v)$ in a mechanical shaker for $60 \mathrm{~min}$ and then centrifuged $(10 \mathrm{~min}$, $3000 \mathrm{rpm}$ ). A solution of the supernatant was transferred to a $25 \mathrm{ml}$ flask extraction was repeated two times. The supernatants were combined and filled to mark by mixture of acetone:water:methanol (7:7:6, $v: v: v)$. The analyses were replicated $(n=3)$, with the contents given as mean values.

\section{Antioxidant activity}

\section{ABTS}

Free radical-scavenging activity was determined by ABTS radical cation decolourization assay described by Re et al. [14]. The ABTS radical cation $\left(\mathrm{ABTS}^{+}\right)$ was produced by reacting ABTS stock solution with potassium per sulphate (final concentration) and kept in the dark at room temperature for $12-16 \mathrm{~h}$ before use. For the study, the $\mathrm{ABTS}^{+}$solution was diluted with ethanol to absorbance of $734 \mathrm{~nm}$. Prior to each analysis, absorbance of Trolox $\left(100 \mu \mathrm{g} \mathrm{ml}^{-1}\right)$ was examined. For the evaluation, $3 \mathrm{ml}$ of diluted $\mathrm{ABTS}^{+}$solution was added to $0.03 \mathrm{ml}$ of polyphenolic extract or Trolox standard and then the mixture was vigorously shaken for $30 \mathrm{~s}$. After $20 \mathrm{~min}$ incubation in the dark the mixture was poured into $\mathrm{cu}$ vettes and the absorbance was read at $734 \mathrm{~nm}$. The scavenging capacity of the extracts was compared with that of trolox $\left(y=917.91 x, R^{2}=0.9989\right.$, ) and expressed as Trolox equivalents (TxE). Results were expressed as Trolox equivalents (TxE). The analyses were replicated $(n=3)$, and the contents given as mean values.

\section{$\mathrm{DPPH}$}

Free radical scavenging capacity of samples was determined using the method proposed by Nuutila et al. [15]. $3 \mathrm{ml}$ of $0.1 \mathrm{M} \mathrm{DPPH}$ methanol solution was mixed with $0.1 \mathrm{ml}$ of polyphenolic extracts or standard solution (Trolox). The mixture was shaken vigorously. After mixing, the tubes were incubated in darkness for $60 \mathrm{~min}$ at room temperature. Then the absorbance was read at $520 \mathrm{~nm}$. Prior to each analysis absorbance of Trolox $\left(100 \mu \mathrm{g} \mathrm{ml}^{-1}\right)$ was examined. The scavenging capacity of the extracts was compared with that of Trolox $(y=355.01 x$, $\left.\mathrm{R}^{2}=0.9997\right)$ and expressed as Trolox equivalents (TxE). The analyses were replicated $(n=3)$, and the contents given as mean values.

\section{Total polyphenol contents}

Total phenolic content was measured in samples before and after the roasting process using the Folin-Ciocalteu colorimetric method described previously by Singleton and Rossi [15]. $0.5 \mathrm{ml}$ extract was mixed with $2.5 \mathrm{ml}$ of the Folin-Ciocalteu reagent and $2 \mathrm{ml}$ of $7.5 \%$ sodium carbonate solution. Total phenolic content was determined after $1 \mathrm{~h}$ of incubation at room temperature. Absorbance of the resulting blue colour was measured at $765 \mathrm{~nm}$ with a UV-VIS spectrophotometer. Quantification was performed with respect to the standard curve of gallic acid. The results were expressed as gallic acid equivalents (GAE). The analyses were 
replicated $(n=3)$, and the contents given as mean values.

\section{Free radicals}

Free radicals were examined using electron paramagnetic resonance (EPR) spectroscopy by measuring free radical EPR signal intensities. The samples were investigated at room temperatures with an EPR spectrometer (RADIOPAN, Poznań, Poland) in a standard chamber, in the X-band $(9.4 \mathrm{GHz})$ with magnetic field modulation of $100 \mathrm{kHz}$. Ruby crystal served as a standard of the EPR relative intensity. The hydrostatic pressure cannot generate radicals, but it may provide an explanation of the processes in their generation and recombination. For this purpose the powder herbal materials (about $1 \mathrm{~g}$ ) were pressurized under hydrostatic pressure of $1 \pm 0.001 \mathrm{GPa}$ in a standard hydraulic press Type WK-18 (Poznań, Poland) for 6, 60, 300 and 1080 min. For EPR study about 45-50 mg of powdered plant material subjected to a pressure of $1 \mathrm{GPa}$ in a hydraulic press has been used.

\section{Statistical analysis}

All data were expressed as mean \pm standard deviation $(n=3)$. Statistical analyses were conducted using Student's $t$-test. Values with $p<0.05$ were considered statistically significant. Statistica 9.0 software (StatSoft, Kraków, Poland) was used for all the analyses.

Ethical approval: The conducted research is not related to either human or animal use.

\section{RESULTS AND DISCUSSION}

In our study, the antioxidant activity, free radical scavengers and total phenolic content were detected in all investigated herbal materials before and after the roasting process (tab. 1). All roasted materials are good sources of bioactive compounds, estimated at the total phenolic levels from 23.9 to $38.8 \mathrm{mg} \mathrm{GAE} / \mathrm{g}$ d.m. (dry matter). Sea buckthorn proved to be the raw material richest in bioactive compounds, for which before the roasting process the total phenolic content was $28.5 \mathrm{mg}$ GAE/g d.m. Antioxidant activity by ABTS and free radical scavenging of DPPH were respectively 82.0 and $54.6 \mathrm{mg}$ TxE/g d.m. Similarly, the highest antioxidant activity by ABTS and DPPH was determined in roasted sea buckthorn at 109.6 and $71.0 \mathrm{mg}$ TxE/g d.m., respectively. In all herbal materials a significant increase was observed for the antioxidant activity and total phenolic content after the roasting process. The biggest increase phenolic compounds was observed for dandelion roots that was up to 5 -fold. In agreement with these data, Lutz et al. [17] and Cepo et al. [18] observed increased antioxidant content and activity in cooked artichoke and roasted carob. Molecular changes and the formation of new compounds were responsible for these changes [19]. The major changes that occur during roasting are the formation of melanoidins in the Maillard reaction and caramelization reactions, which produce compounds with strong antioxidant properties [20].

Despite high content of compounds with potent antioxidant activity, the results of the present study revealed the presence of native free radicals in novel herbal materials for the production of chicory coffee (tab. 2). The concentrations in raw materials ranged from 0.001 to $0.097 \times 10^{15} \mathrm{spin} / \mathrm{g}$. Roasted materials were characterised by markedly higher free radical concentrations when compared with the corresponding samples. The content of free radicals increased by roasting process of 1.5 -fold for lovage roots up to 35 -fold for rowanberry. The lowest free radical concentrations were obtained for roasted sea buckthorn fruits $\left(0.031 \times 10^{15} \mathrm{spin} / \mathrm{g}\right)$, while the highest for roasted dandelion roots $\left(0.27 \times 10^{15} \mathrm{spin} / \mathrm{g}\right)$. The free radical concentrations in roasted dandelion roots and lovage roots were considerably higher than those of roasted sea buckthorn fruits and rowanberry. The roasting process caused an increased free radical content in coffee beans $[7,8]$. Also some of the common, conventional food processing techniques such as e.g. microwave roasting, pan-frying, grinding or mixing to power also resulted in the generation of free radicals, but to variable extents [21].

Figure 1 shows an example of the EPR spectrum obtained for dandelion roots. The differences in the intensity of EPR signals indicate the amount of radicals. A shift of the EPR signal may be observed for the roasted material, which may indicate certain processes of recombination of radicals under the influence of roasting.

The influence of pressurizing time under pressure of $1 \mathrm{GPa}$ on natural radicals in the unroasted and roasted herbal materials was also investigated by EPR. However, the results are ambiguous and require a more detailed analysis. 
Table 1.

Antioxidant activity and total phenolic content of plant raw materials

\begin{tabular}{|c|c|c|c|c|}
\hline Discriminant & Sea buckthorn fruits & Rowanberry & Lovage roots & Dandelion roots \\
\hline \multicolumn{5}{|c|}{ Before roasting } \\
\hline \multicolumn{5}{|l|}{$\begin{array}{l}\text { Antioxidant activity: } \\
\text { [mg Tx/g d.m.] }\end{array}$} \\
\hline ABTS & $82.0 \pm 0.3^{\mathrm{a}}$ & $15.2 \pm 0.2^{\mathrm{a}}$ & $24.5 \pm 0.3^{\mathrm{a}}$ & $13.3 \pm 0.2^{\mathrm{a}}$ \\
\hline $\mathrm{DPPH}$ & $54.6 \pm 0.5^{\text {a }}$ & $16.5 \pm 0.4^{\mathrm{a}}$ & $14.2 \pm 0.3^{\mathrm{a}}$ & $5.2 \pm 0.1^{\mathrm{a}}$ \\
\hline Total phenolic content [mg GAE/g d.m.] & $28.5 \pm 0.1^{\mathrm{a}}$ & $12.6 \pm 0.2^{\mathrm{a}}$ & $12.8 \pm 0.5^{\mathrm{a}}$ & $5.9 \pm 0.1^{\mathrm{a}}$ \\
\hline \multicolumn{5}{|c|}{ After roasting } \\
\hline \multicolumn{5}{|l|}{$\begin{array}{l}\text { Antioxidant activity: } \\
\text { [mg Tx/g d.m.] }\end{array}$} \\
\hline ABTS & $109.6 \pm 0.2^{b}$ & $59.3 \pm 0.4^{b}$ & $52.9 \pm 0.2^{b}$ & $61.5 \pm 0.4^{\mathrm{b}}$ \\
\hline DPPH & $71.0 \pm 0.5^{b}$ & $45.3 \pm 0.3^{\mathrm{b}}$ & $24.3 \pm 0.3^{\mathrm{b}}$ & $32.1 \pm 0.4^{\mathrm{b}}$ \\
\hline Total phenolic content [mg GAE/g d.m.] & $38.8 \pm 0.3^{b}$ & $31.1 \pm 0.9^{\mathrm{b}}$ & $23.9 \pm 0.4^{b}$ & $28.1 \pm 0.3^{\mathrm{b}}$ \\
\hline
\end{tabular}

Results are presented as means \pm standard deviation $(n=3)$. Values in each column denoted with different letters differ significantly at $p<0.05$ as measured by Student's $t$-test.

Table 2.

Free radical levels of plant raw materials [spin/g]

\begin{tabular}{cccc}
\hline Sea buckthorn fruits & Rowanberry & Lovage roots & Dandelion roots \\
\hline \multicolumn{3}{c}{ Before roasting } \\
\hline $0.011 \times 10^{15}$ & $0.001 \times 10^{15}$ & $0.097 \times 10^{15}$ & $0.012 \times 10^{15}$ \\
\hline \multicolumn{3}{c}{ After roasting } \\
\hline $0.031 \times 10^{15}$ & $0.035 \times 10^{15}$ & $0.150 \times 10^{15}$ & $0.270 \times 10^{15}$ \\
\hline
\end{tabular}

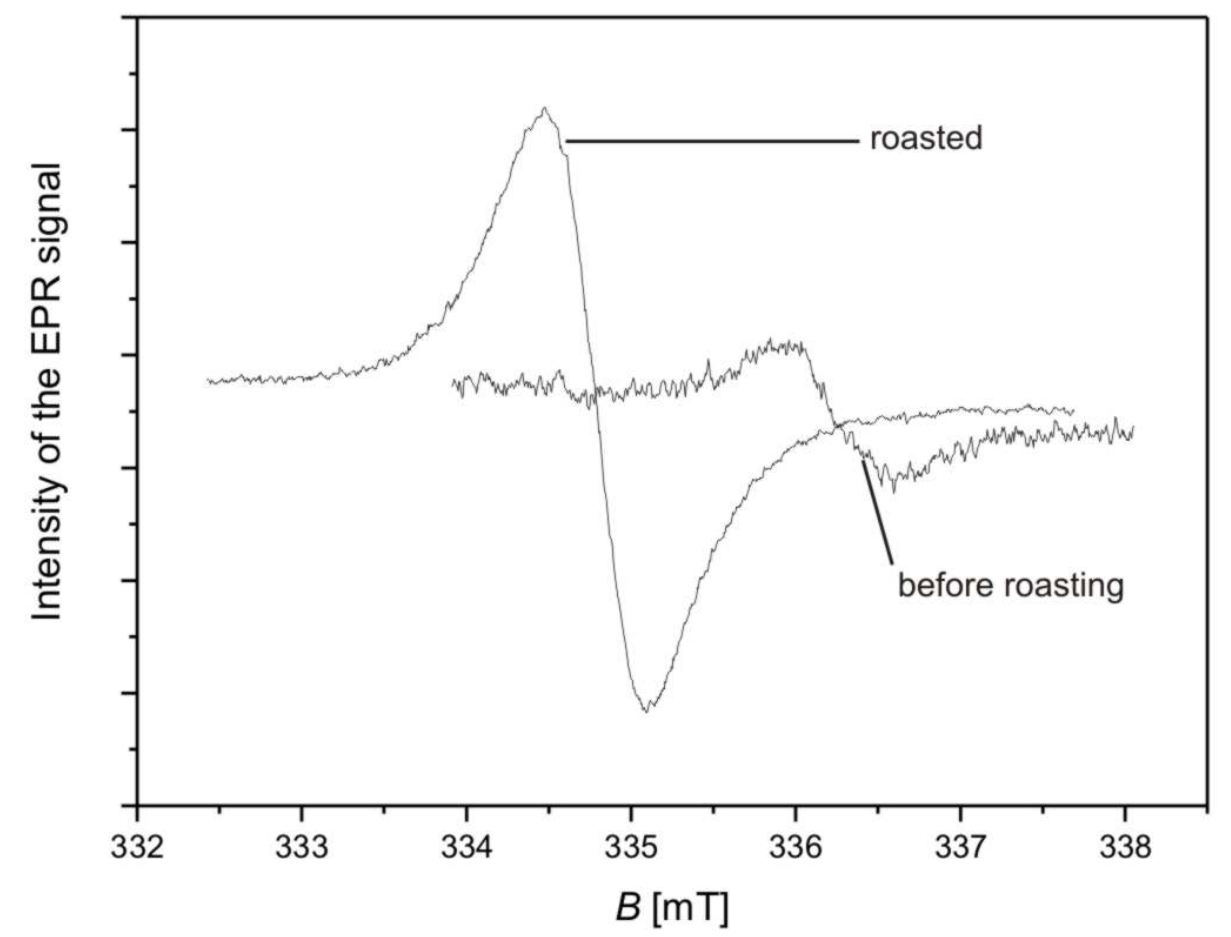

Figure 1.

Example of the EPR spectrum obtained for dandelion roots before and after roasting process, B - magnetic induction 


\section{CONCLUSIONS}

All novel herbal materials for chicory coffee are characterized by high antioxidant activity and total phenolic content. These properties significantly increased after the roasting process. Sea buckthorn fruits and rowanberry are the best raw materials for chicory coffee in terms of high content of phenolic compounds and a low free radicals. Despite a high content of compounds with potent antioxidant activity, free radicals were present in novel roasted herbal materials. The formation of both antioxidant molecules and free radicals during the roasting process demonstrates that the two processes were not inversely related.

Conflict of interest: Authors declare no conflict of interest.

\section{REFERENCES}

1. Prof. Wacław Dąbrowski Institute of Agricultural and Food Biotechnology, (Pl) Chicory coffee with herbs. Inventors: Korbas E, Bodył P, Dudarski L, Wojtowicz E, Remiszewski M, Hoppel H. Polish Patent Office, Pl 218168 B1. 24.06.2013

2. Zawirska-Wojtasiak R, Wojtowicz E, Przygoński $\mathrm{K}$, Olkowicz M. Chlorogenic acid in raw materials for the production of chicory coffee. J Sci Food Agric 2014; 94:2118-23. doi: http://dx.doi. org/10.1002/jsfa.6532

3. Zeb A, Ullah S. Sea buckthorn seed oil protects against the oxidative stress produced by thermally oxidized lipids. Food Chem 2015; 186:6-12. doi: http:/dx.doi.org/10.1016/j.foodchem.2015.03.053

4. Suryakumar G, Gupta A. Medicinal and therapeutic potential of Sea buckthorn (Hippophae rhamnoides L.). J Ethnopharmacol 2011; 138:268-278. doi: http:/dx.doi.org/10.1016/j.jep.2011.09.024

5. OlszewskaM. Separation of quercetin, sexangularetin, kaempferol and isorhamnetin for simultaneous HPLC determination of flavonoid aglycones in inflorescences, leaves and fruits of three Sorbus species. J Pharm Biomed Anal 2008; 4:629-635. doi: http:/dx.doi.org/10.1016/j.jpba.2008.06.004

6. Williams A, Goldstone F, Greenham J. Flavonoids, cinnamic acids and coumarins from the different tissues and medicinal preparations of Taraxacum officinale. Phytochemistry 1996; 42:121-127. doi: http://dx.doi.org/10.1016/0031-9422(95)00865-9

7. Goodman BA, Pascual EC, Yeretzian C. Real time monitoring of free radical processes during the roasting of coffee beans using electron paramagnetic resonance spectroscopy. Food Chem 2011; 125:248-254. doi: http:/dx.doi.org/10.1016/j. foodchem.2010.07.072

8. Yeretzian C, Pascual EC, Goodman BA. Effect of roasting conditions and grinding on free radical contents of coffee beans stored in air. Food Chem 2012; 131:811-816. doi: http:/dx.doi.org/10.4236/ as. 2013.48058

9. Getoff N. Anti-aging and aging factors in life. The role of free radicals. Radiat Phys Chem 2007; 76:1577-86. doi: http:/dx.doi.org/10.1016/j.radphyschem.2007.01.002

10. Sudha K, Rao AV, Rao S, Rao A. Free radical toxicity and antioxidants in Parkinson's disease. Neurology India 2003; 5:60-62. doi: http://www.neurologyindia.com/ text.asp?2003/ 51/1/60/1032

11. Trilling JS, Jaber R. Selections from current literature: the role of free radicals and antioxidants in disease. Fam Pract 1996; 13:322-326. doi: http:/ dx.doi.org/10.1093/fampra/16.5.534

12. Kośmider L, Knysak J, Gawron M, Czogała J, Goniewicz MŁ. Free radicals in tobacco smoke analytical approach and biomedical significance. Environ Med 2013; 16:7-14.

13. Moure A, Cruz JM, Franco D, Dominguez JM, Siniero J, Nunez MJ, Parajo JC. Natural antioxidants from residual sources. Food Chem 2001; 72:145-171. doi: http:/dx.doi.org/10.1016/S03088146(00)00223-5

14. Re R, Pellegrini N, Prollegente A, Pannala A, Yang $\mathrm{M}$, Rice-Evans CA. Antioxidant activity applying an improved ABTS radical cation decolorization assay. Free Radic Biol Med 1999; 26:1231-35. doi: http:/dx.doi.org/10.1016/S0891-5849(98) 00315-3

15. Nuutila AM, Puupponem-Pimia R, Aarni M, Oksman-Caldentey K-M. Comparison of antioxidant activities of onion and garlic extracts by inhibition of lipid peroxidation and radical scavenging activi- 
ty. Food Chem 2003; 81:485-493. doi: http:/dx.doi. org/10.1016/S0308-8146(02)00476-4

16. Singleton VL, Rossi JA. Colorimetry of total phenolics with phosphomolybdic - phosphotungistic acid reagents. Am J Enol Vitic 1965; 16:144-158

17. Lutz M, Henríquez C, Escobar M. Chemical composition and antioxidant properties of mature and baby artichokes (Cynara scolymus L.), raw and cooked. J Food Compos Anal 2011; 1:49-54. doi: http:/dx.doi.org/10.1016/j.jfca.2010.06.001

18. Cepo DV, Mornar A, Nigovic B, Kremer D, Radanovic D, Dragojevic IV. Optimization of roasting conditions as an useful approach for increasing antioxidant activity of carob powder. LWT-Food Sci Technol 2014; 58:578-586. doi: http:/dx.doi.org/10.1016/j.lwt.2014.04.004
19. Kweon MH, Hwang H J, Sung HC. Identification and antioxidant activity of novel chlorogenic acid derivatives from bamboo (Phyllostachys edulis). J Agric Food Chem 2001; 49:4646-55. doi: http:/ dx.doi.org/10.1021/jf010514x

20. Yanagimoto K, Lee KG, Ochi H, Shibamoto T. Antioxidative activity of heterocyclic compounds found in coffee volatiles produced by Maillard reaction. J Agric Food Chem 2002; 50:5480-84. doi: http:/dx.doi.org/10.1021/ jf025616h

21. Bhat R, Sridhar KR. Influence of ionizing radiation and conventional food processing treatments on the status of free radicals in lotus seeds: An ESR study. J Food Compos Anal 2011; 24:563-567. doi: http:/dx.doi.org/10.1016/j.jfca. 2010.12.008

\title{
Własności antyoksydacyjne i wolne rodniki prażonych surowców zielarskich
}

\author{
ELŻBIETA WOJTOWICZ ${ }^{1 *}$, ALDONA KRUPSKA², RENATA ZAWIRSKA-WOJTASIAK ${ }^{3}$
}

${ }^{1}$ Zakład Koncentratów Spożywczych i Produktów Skrobiowych

Instytut Biotechnologii Przemysłu Rolno-Spożywczego im. prof. Wacława Dąbrowskiego

ul. Starołęcka 40

61-361 Poznań

${ }^{2}$ Instytut Fizyki Molekularnej

Polska Akademia Nauk

ul. Smoluchowskiego 17

60-179 Poznań

${ }^{3}$ Wydział Nauki o Żywności i Żywieniu

Uniwersytet Przyrodniczy w Poznaniu

ul. Wojska Polskiego 28

60-637 Poznań

*autor, do którego należy kierować korespondencję: tel.: +48 618731 989, e-mail: ewojt@man.poznan.pl

\section{Streszczenie}

Wstęp: Ciągle poszukuje się nowych atrakcyjnych surowców, które przez swój specyficzny skład będą uatrakcyjniać aromat kawy zbożowej. Surowce zielarskie (rokitnik, owoce jarzębiny, korzenie lubczyka, ko- 
rzenie mniszka lekarskiego) zostały poddane procesowi prażenia, który zmienia właściwości przeciwutleniające i generuje wolne rodniki o właściwościach prooksydacyjnych.

Cel: Charakterystyka działania przeciwutleniającego prażonych surowców zielarskich (owoców rokitnika, jarzębiny, korzenia lubczyku i korzenia mniszka lekarskiego) i określenie poziomu wolnych rodników powstających pod wpływem prażenia.

Metody: Oznaczano całkowitą zawartość polifenoli przed i po procesie prażenia za pomocą odczynnika Folin-Ciocalteu i aktywność przeciwutleniającą za pomocą testów ABTS i DPPH. Wolne rodniki badano za pomocą spektroskopii elektronowego rezonansu paramagnetycznego (EPR).

Wyniki: Prażone zioła były dobrym źródłem związków bioaktywnych. Całkowita zawartość związków fenolowych wynosiła od 23,9 do 38,8 mg GAE/g. Najwyższa aktywność przeciwutleniająca mierzona za pomocą testów ABTS i DPPH została ustalona dla rokitnika, która wynosiła odpowiednio 109,6 i 71,0 Tx/g. Wolne rodniki były obecne we wszystkich badanych surowcach. Materiały prażone charakteryzowały się znacznie wyższym poziomem wolnych rodników. Najniższe stężenie wolnych rodników odnotowano w prażonych owocach rokitnika $\left(0,031 \times 10^{15} \mathrm{spin} / \mathrm{g}\right)$.

Wniosek: Mimo wysokiej zawartości związków o silnej aktywności przeciwutleniającej wolne rodniki powstawały podczas prażenia badanych ziół.

Słowa kluczowe: zioła, rokitnik, jarzębina, lubczyk ogrodowy, mniszek lekarski, proces prażenia, własności antyoksydacyjne, wolne rodniki 